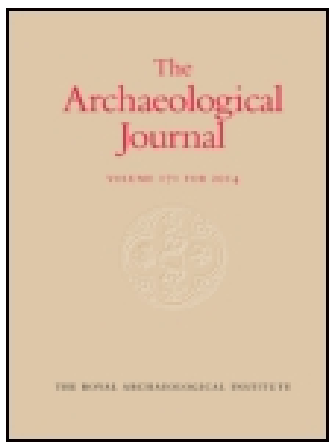

Archaeological Journal

\title{
On the Indoor Games of School Boys in the Middle Ages
}

\section{J. T. Micklethwaite F.S.A.}

To cite this article: J. T. Micklethwaite F.S.A. (1892) On the Indoor Games of School Boys in the Middle Ages, Archaeological Journal, 49:1, 319-328, DOI: 10.1080/00665983.1892.10852528

To link to this article: http://dx.doi.org/10.1080/00665983.1892.10852528

曲 Published online: 15 Jul 2014.

Submit your article to this journal $\pi$

Q View related articles $\sqsubset$

4 Citing articles: 1 View citing articles 


\title{
Arctiaglogical journal.
}

\author{
DECEMBER, 1892. \\ ON THE INDOOR GAMES OF SCHOOL BOYS IN THE \\ MIDDLE AGES.
}

By J. T. MICKLETHWAITE, F.S.A.

About twenty years since I became convinced, for reasons to be given later, that certain "cup markings" arranged in squares of nine in the benches of the cloister of Westminster Abbey, are the work of school boys in the monks' time, and not as at first seemed likely of those of the present school, who for years used the cloister for a playing place. In $1875 \mathrm{I}$ mentioned them, and tried to explain their meaning in a paper on the Abbey buildings of Westminster, which is printed in the thirty-third volume of the Archoological Journal. I soon found like markings in other places especially in cloisters, and after a time noticed other markings associated with them. Some of these are only scratched on the stone, and not seen till looked for, and I do not doubt that I passed over others like them, before I had learned to look. I have often directed the attention of members of the Institute to these things, when we have met with them during our country meetings, and although they are but trifles, I think they are worth a more lasting notice, before the demon "Restoration" sweeps them all away with other things of more importance.

For some years Mr. St. John Hope, has been noting such examples as he has found, and he has passed on his collection to me for use in this paper, which, therefore, gives the result of his labour as well as mine.

The "board" of nine holes (Fig. 1) is found on the benches of the Benedictine cloisters of Westminster, Canterbury and Norwich, and of the secular cloister of Chichester. And the device shown on Fig. 2, which gives nine points, vol. XLIX (No. 196). 
and belongs to the same game as Fig. 1, exists in the cloisters of Norwich and Gloucester, and in that of Salisbury. These are a fair proportion of the old English cloisters which the destroyer and the "restorer" have allowed to remain. But search, in any, seldom fails to detect examples of these play boards, or of the others shortly to be described.

They are also sometimes found in other places. There are examples of both Fig. 1 and Fig. 2, cut into a stone bench in the north porch of the parish church of Ardeley, in Hertfordshire, and one of Fig. 1, cut on a fifteenth century pew, in the church of Heydon, in Norfolk, and there is even one on an altar step in the south east chapel of the north transept of the Cathedral church of Lincoln. I am not quite sure that this last is a board for playing on. It may have had another use, but a drastic "Restoration" has taken away such evidence as there may have been to tell of it ${ }^{1}$

All the examples quoted so far have been found in or about churches, and it will generally be so with the other kinds of boards to be described soon. But that comes only of the greater permanence of church buildings. There is not anything in the games specially either clerical or ecclesiastical, and they were played generally in houses and in the fields, although the visible traces of them seldom remain. What may be an example of an outdoor playboard was described, at a meeting of the Society of Antiquaries on 20th January, 1887, and a photograph of it shown by the Rev. E. B. Savage. It is a stone from the fence of an old graveyard at Ballagawn, Arbory, in the Isle of $\mathrm{Man}^{2}$ On it are, amongst other cup-shaped sinkings, nine arranged as in Fig. 1. The date is very uncertain, but, judging from the photograph only, I thought it mediæval. It should, how-

1 This is a good example of the purely mischievous "restoration" of which antiquaries complain. Every thing is new except the one old stone with the holes in it, and that his been trimmed up, and there is no warrant that it is iu its old place. If this had been done to meet some modern need there would have been an excuse for it. But the chapel is not used, and without altar, and the destruction of the old steps was only a sicrifice to that morbid desire to hare all things new which possesses so many of those who have the keeping of our ancient buildings. The men who did the work no doubt thought themselves very "con. servative " because they left this one old stone, which even they could see had an interest of its own. They have made it look like a patch of old faded cloth of golk in a smart new coat of broadcloth.

2 Proceedings Society of Antiquaries, 2nd Series xi., 1. 239. 
ever, be noticed that every group of nine holes arranged in a square is not a play board. Sometimes the position shews this, as, for example, two small ones, the work of some idle fellow, on the east outside jamb of the south door of the nave of Kemscott Church, Oxon, which could not be played upon, though the form may have been suggested by the play board. A cresset stone of nine cups might take the same form, but I do not remember to have seen one with it.

The game for which these boards were made is still played on curbstones and doorsteps, but I have not found it described in any of the books. The only name for it I lave met is Knockings in and out, which is, or was, a few years ago in use in London. I think I have met with In and out as the name of a childish game, but I cannot now find the passage. Nine lioles is sometimes mentioned, but I believe that to be the name of a game of a different kind. The "men" in our game are pebbles or fruit stones, which, with the bones of animals used for food, have served for" playthings from the beginning of the human race. Each player has three, and they begin by setting them down alternately, the object of each being to get his three men in a row, exactly as in the game of tick, tack, toe; or oughts and crosses, which I suppose still survives wherever slate and pencil are used as implements of education. If neither player succeeds in the setting on of the men, which should be the case if both are awake, they move their men alternately along the lines of Fig. 2 until one gets his three in a line.

I describe the game as I found it played in London, and there is more play in it than might be thought from the simplicity of the directions. Its fault, so far as I have tried it, is that it is apt to run into a dead lock, in which each player has one or two moves backwards and forwards, which neither help his game nor spoil his adversary's. There may once have been complications in the game which are lost now. Each of the Westminster boards has a line cut from the central hole to the middle one of one side, and this most likely had a meaning in the game. And at Norwich some of the boards have both lines and holes, but with the middle hole much larger than the others, as in Fig. 3. This may be only caprice, or it may 
be intended to make the board serve also for the play with huckle bones which we shall come to soon.

Fig. 4 shews a board which is found cut in several places on the benches of the cloister's at Gloucester and Salisbury, and $\mathrm{Mr}$. Hope found another, cut on a stone taken from an old wall in Scarborough Castle, and evidently intended to be played upon before the stone was set. It belongs to the game of Nine men's morris, which is remembered now chiefly from Shakespeare's mention of it, in a well known passage. ${ }^{1}$ I have never met with anyone who played the game, but I doubt not it is still played, for I have seen the board chalked on a doorstep in London, and pebbles lying on it within the last twenty year's. Strutt describes it, and others after him. But his rules need supplementing by any who wish to play the game. I have tried it, and find it at least as good a game as draughts. It may be considered an expanded form of the In and Out game, Each player has nine men, and the board gives twenty-four points. The players set their men on the board alternately, each trying to get three of his own in a row. When he has made a three, he may take off any one of his adversary's men that he chooses, except that he may not break into an already made three if he can obtain his due without it. When all the men are on the board the players move them from point, to point along the lines, still trying to make threes, until one wins by taking all the other's men.

Some rule is wanted to regulate the re-forming of threes, as that the same three men shall not count twice upon the same points. And there is a doubt whether in the old game, the men could be moved and threes formed diagonally at the corners. The old boards have not diagonal lines there, though modern ones have. The game may be played either way, and from my small experience, I will not venture an opinion as to which is the better.

Fig. 5 is the board for $F_{O x}$ and Geese. It is found on the cloister benches of Gloucester Cathedral and elsewhere, and there are several on the twelfth century tomb at Salisbury mis-called Lord Stourton's, and moved from the choir into the nave at Wyatt's "restoration." The game is now played on a wooden board, marked as Fig. 5, and with

${ }^{1}$ Midsummer Niglt's Dream, act ii, sc. 2. 
holes at the points, and pegs to play with. I remember having a set given me when I was a boy, and although we voted the game poor fun, the board and pegs were turned to a variety of good uses.

Fig. 7 shews the setting on of the pieces. The black spot in the middle is the fox, and the seventeen white ones are the geese. The pieces are moved from point to point along the lines and only one point at a time, except that the fox takes by jumping over a goose next to him. if the point beyond is free. The object of the fox, is thus to take all the geese, and the geese try to shut in the fox so that he cannot move, in which case he is beaten. If the geese were anything else but geese, the fox would have no chance in the game.

Fig. 6, which is from Gloucester. looks more like a variety than an unfinished example of Fig. 5, but it may be either.

One round hole scooped in a stone with a knife is scarcely enough even for an antiquary to raise a theory on. It may have been made by anybody at any time. But when a number of them are found associated with figures which are known to be play boards, it is a fair inference that some at least of them have been made for like use. And many single holes are found on the same benches as the figures already described.

Some games now played with marbles could be played on these holes. But the marble, although without doubt it is nearly allied to the pebble, is itself but a modern. It is the product of civilisation and commerce, a manufactured toy, a shop thing implying the possession of pocket-money by those who use it. The implements of really primitive games were not bought but found, and the only tool used about them was the knife, which has been part of a schoolboy's outfit ever since the days of Cadmus.

The games for which these single holes were made were, I believe, some of those exercises of dexterity of hand by throwing and catching, which seem to have always been in use, and are so still. So lately as my mother's girl-days - some sixty years ago-they were practised in English ladies' schools, but I do not think they are to be found there now. Then they still used bones, the small bones of calves' feet, from which jelly was made before modern science taught 
the cooks to make it of glue. They had also substitutes of earthenware made somewhat after the form of the bones, and I can remember such when I was a boy, though I cannot remember ever to have seen the actual bones used. In Lancashire they called the things in either form jacks. In Yorkshire we now call them checks, or more commonly since the change of material, pot checks. I exhibit a set4 checks and a ball-lately bought in Wakefield for a halfpenny. These shew a sad falling off from the ancient form, though I can still see in them a memory of the bone from which they are derived. As a game which has come down by tradition from the remotest times, the modern form of it has an interest for antiquaries, and as I have not found it described in any book, I have put into a note at the end of this paper, a description of it gathered from experts by the lady to whose kindness I owe the specimens of the checks.

I have no doubt that some form of the game was played in some of the holes which we find on the benches in cloisters and church porches. In playing with pot-checks a ring is drawn on the stone which serves for a table, but I have seen a hole used.

Cherry pit, which is no more than trying to throw a handful of cherry stones or the like, so that all shall fall into the hole, is another probable game.

I have described the boards most often found, but there are others, and some of them I can not explain the use satisfactorily, and I shall be glad of help from any who can give it. At Salisbury there is a chequer board of sixteen squares (Fig. 8) cut on the bench on the Garth side of the East Cloister walk. It is carefully done, and the alternate squares are slightly sunk shewing that the squares were played upon and not the points of intersection. The form suggests something like draughts, which we play on a board of sixty-four squares only because we use a chess board. There is not anything in the game to require that number, but it cannot be played on a board of less than twenty-five. So this of sixteen must have been used differently.

On the bench, in the second bay from the eastern church door, in the cloister of Norwich Cathedral, are eight small holes in a right line, which were probably used in some game 
In works recently carried out at Norwich Castle, several game boards cut upon stones have been brought to light, amongst them an in and out board and a morris board and one for fox and geese. There is also one with a number of parallel lines, divided down the middle by one line at right angles with the others (Fig. 9). This is for the game of tables, which now survives as backgammon. There were various ways of playing, but in all each player had to bring forward his men from point to point by alternate throws of the dice until one of them won by taking his all home or out of the board. The use of dice is not against the antiquity of the game, for any boy could make them for himself. I remember them being made at school by rubbing down marbles. ${ }^{1}$ and properly selected pebbles would serve as well. The earliest dice, however, were natural bones, and they are amongst the most ancient and widely distributed of playthings.

Another very curious board from Norwich castle is a long spiral line of seven turns, with holes at the start and in the middle, and eighty-three smaller holes or points at about equal distances along the line. The line is continued outwards and has three small holes and a final larger one, beyond that which I have assumed to be the start. (Fig. 10.) I have not any evidence as to the game played on this, but I suspect that it also was played with dice, and was something like the modern steeple chose game, each player moving his piece forward according to his throw, and probably having to go back or to lose his turn, if he lighted on a point already occupied.

In conclusion something must be said about the date of these play boards. Those which have been found built up in walls must be as old or older than the walls. Most of them were probably made by the builders of the walls to play on during their leisure time, and so were of the same date. I do not know whether the Norwich examples were found in position, or the age of the walls from which they

1 This was merely for the pleasure of the making. We did not play with dice. The school equivalent was a scoperil, which was a sort of top spun with the fingers, and having six or eight sides which were numberel. A piece of card- board cut the required shape and with a peg-generally a bit of slate pencilthrust through it made a scoperil. We sometimes played with it fur nuts, but sitting down games of any sort were little used by us. 
came. But Mr. Hope says that the Scarborough stone came from a fourteenth century wall, and he is as good a judge of such a matter as most men.

For the last three centuries and a half cloisters everywhere in England have been open passages, and there have generally been schoolboys about. It is therefore not unlikely that they should have left behind them such traces as these play boards. But if they are of later date they would not be found to be distributed in monastic cloisters with respect to the monastic arrangement; and we do find them so. At Westminster Abbey they are only found in the north-west corner, which, if the arrangement agreed with that at Durham, as there is reason to believe it did, was the place of the school. At Norwich, where the game boards are very many, they are found in every part of the cloister except the north walk, where the monks had their library and studies. At Gloucester the morris and fox and geese boards are in the north walk, and the simpler in and out boards in the west walk, and none is found in the south, which was the monks' side, or in the east, which was most used by them as a passage way. At Canterbury the play boards are found only in the south walk, which is that against the church, and so according to the usual plan it would be the monks' place. But I think it was not so there, as that walk was the passage between the Archbishop's palace and the quire. We do not really know what the arrangement of the cloister was at Canterbury.

In the secular cloister of Salisbury the boards are only found in the east walk between the Chapter House door and that towards the Bishop's Palace. I can give no reason for this, unless it be that a school was kept there, which is not unlikely. We know that till comparatively late times school was held in the Cloister at Winchester College during the summer.

As the games themselves did not die out it is remarkable that all the boards noticed are cut upon stone or wood, which was wrought at the latest before the middle of the sixteenth century. And this is a further confirmation of their antiquity.

Perhaps an apology is due to the Institute for taking up time with such small matters, but to me the games 
which amused the children who were our own ancestors are as interesting as those over which Davus and Geta idled away their time and quarreled in the Roman forum.

NOTE.

ON THE MANNER OF PLAYING WITH POT CHECKS AT WAKEFIELD.

The set of pot checks, which represents five huckle bones, now consists of four checks and a ball about the size of a large marble. The checks are something like dice, but only two opposite sides are plain, the other four being fluted. The table played on is generally a doorstep, and it is made ready by drawing a ring upon it with anything handy which will make a mark-ours is not a chalk country. There are twelve figures or movements to be gone through as follow. Some have special names, but I do not learn that all have.

I. The player, taking the checks and ball in the right hand, throws down the checks, keeping the ball in the hand. If any check fall outsicle the ring the player is "down." There is skill needed in the throwing of the checks in this and the following movements, so that they may be conveniently placed for taking up in the proper order. The checks being scattered, the player throws up the ball, takes up one check, and catches the ball as it comes down, or, as it is sometimes played, after it has bounced once from the step. This is repeated till all the checks are taken up.

II. As the last figure, but the checks are taken up two at a throw.

III. As the last, but at the first throw one check, called the horse, is taken up, and at the second the remaining three checks at once, called the cart.

IV. As before, but all the checks taken up together.

V. Called ups and clowns. The checks are taken up at one throw, and set down outsicle the ring at the next. This is done first with one, then with two, and so on.

VI. Each check is touched in turn as the ball is thrown.

VII. The checks as separately pushed out of the ring.

VIII. Each check in turn is taken up and knocked against the ground. 
IX. Each check is taken up and tapped upon another.

$\mathrm{X}$. The checks are first arranged three in a line, touching each other, and the fourth placed at the top of that at one end of the row. This is called the cradle. It has to be taken down check by check, and if, in taking one, another is moved the player is out.

XI. Like the last, but the checks are put one above another to make a chimney.

XII. Called the dish clout. I know not why, unless it be that it wipes up the game. The movement used in taking up the checks is thus described:- "Take hold of the sleeve of the right hand with the left; throw up the ball, and twist your right hand underneath and over your left, and catch the ball. With the hand still twisted throw up the ball and untwist and catch it." The checks are picked up in the course of the twisting.

These I am told are the orthodox movements; and I do not doubt that in them there is much of very old tradition, although the tenth and eleventh must have been either added or modified since poti checks came into use, for the figures could not be built up with the natural bones. Some other movements are sometimes used according to fancy, as for example the clapping of the ground with the palm of the hand, before taking up the checks and catching. the ball. My authority does not mention the form of play which classical students know best-that in which the bones were thrown up and caught on the back of the hand. But I believe it is played with pot checks with a difference, the checks - five or more-being thrown from the back of the hand and caught in the palm.

I am told that in the iron districts of Staffordshire, the round bits of iron punched out in making rivet holes in boiler plates, are the modern representatives of huckle bones. 